\title{
Analysis of Inter-Country Trade Flows Based on Input - Output Model Between Vietnam - EU - China and the United States
}

\author{
Thai Nguyen Quang ${ }^{1} \&$ Trinh Bui ${ }^{1}$ \\ ${ }^{1}$ Vietnam Development Research Institute, Hanoi, Vietnam \\ Correspondence: Trinh Bui, Vietnam Development Research Institute, Hanoi, Vietnam.
}

Received: May 17, 2021

Accepted: June 14, 2021

Online Published: June 23, 2021

doi:10.5430/rwe.v12n3p88

URL: https://doi.org/10.5430/rwe.v12n3p88

\begin{abstract}
In recent years, although the balance of trade in goods of Vietnam has always been surplus for many years but the real domestic economy has been also deficit. People were thrilled for that achievement. The study attempts to estimate how the trade flows between the four countries Vietnam, China, the United State (US) and the Europe (EU) induce to output and value added of each country?

The research used inter - country input - output model between those countries for analyzing the effects of trade flow to the economy of each country, especially for Vietnam.
\end{abstract}

Keywords: final demand, final products, input, inter-country, output, value added

\section{Introduction}

In recent years, Vietnam participates in many bilateral and multilateral trade agreements. The database on import and export of goods and service shows that Vietnam always has a trade surplus with the United States, the EU and Japan, whilethe trade balance with China and South Korea tends to be gradually negative. Particularly, Vietnam's trade deficit from China significantly increased to 2.7 times, from 12.5 billion USD in 2010 to 34 billion USD in 2019. Saw the same trend in South Korea, the trade deficit was 6.6 billion USD in 2010 then went up to 27.3 billion USD in 2019. On the contrary, Vietnam has experienced an increase in trade balance with the US, the EU and Japan since 2019. The trade surplus with the US and the EU grew up from 10.5 billion USD and 5 billion USD in 2010 to 47 billion USD and 26.6 billion USD in 2019 respectively. It also increased in Japan. In total, Vietnam's trade surplus with the US, Japan and the EU was about 74 billion USD and the trade deficit with China and South Korea was about 61.3 billion USD in2019.

According to estimates from Vietnam General Statistics Office, export and import of goods and service to the EU could slightly decrease in 2020 (exports decreased by about $15 \%$ and imports decreased by about $2 \%$ ). Moreover, the exports to the US rose dramatically by 26\% and imports from the US decreased by about 5\% from 2019 to 2020. This led to the trade surplus with the US in 2020 increased by about $35 \%$ compared to 2019 (from 46.9 billion USD in 2019 to 63.1 billion USD in 2020). Meanwhile, the trade deficit with China and South Korea in 2020 increased by about 3\% compared to 2019 (from 61.3 billion USD to 63 billion USD). Thus, the trade surplus between Vietnam and the US is equivalent to the total of trade deficit between Vietnam-China and Vietnam-Korea. The research shows that exports of Vietnam does not induce much to Vietnam's production and value-added but to the production and value-added of the countries where Vietnam imports raw materials as intermediate input. This study tries to find out evidence for this problem and give some policy implications to restructure the economy so that the economy develops harmoniously and sustainably.

The products that Vietnam exports to the US and the EU are basically outsourcing products (eg phones and components account for about $15 \%$ of the total exports of goods to the US) and products for final consumption (eg textiles and footwear accounts for $35 \%$ of total merchandise exports to the United States). 


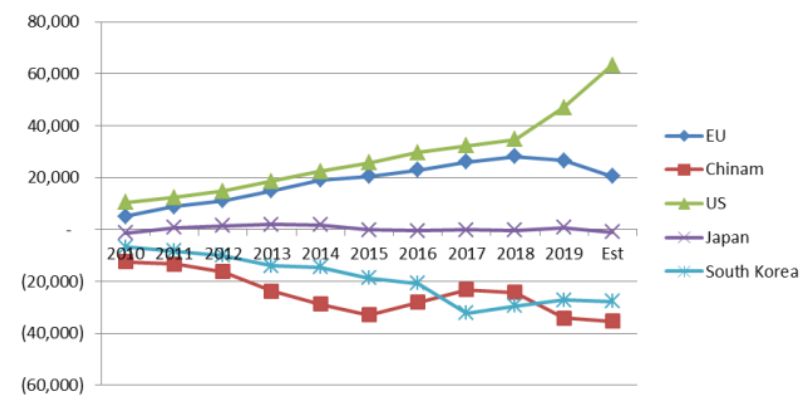

Figure 1. Net export of Vietnam with EU, China, US, Japan and South Korea (Unit: Billion USD) Source: Vietnam General Statistics Office, gso.gov.vn

The inter - country input - output table are the linkage of national input - output tables through trade transactions between countries to help policy makers see the influence of each other in commercial transactions.

The national input - output table bases on the most basic understanding that production, value added, import ... are influenced by the interagency relationship and final demand. The inter-country input - output model measures the variation in production and income by one country induced by another country's production and consumption. The effects on output of a country includes: Multiplier effects, inter - national feedback effects and spillover effects.

\section{Literature Reviews}

The ideas of regional linkage were first mentioned by Walter Isard (1951), and then he himself developed the method of regional analysis $(1956,1960)$. Then Miller $(1966,1969)$ developed the inter-regional analysis method with the notion of interregional feedback effects. Parallel to these studies was a series of papers by Miyazawa (1960, 1966, 1968, 1971) on interregional analysis; however, according to Michel Sonis and Geoffrey Hewing (1999) give that, these contributions were not appreciated outside of Japan until the publication of a monograph (Miyazawa, 1976 and Richardson, H. W. 1979) that first brought them to the attention of modelers in regional science. After that, ideas on multiregional multipliers were given by two papers by Sonis and Hewing $(1993,1885)$ o further into explaining the interregional structure. The issue of feedback effectsis revisited by Takeo Ihara (1999), he separates the problem into two components - diagnosis (analysis of regional issues) and therapy (policy recommendations)- and explores this distinction in the context of the Japanese interregional system.

Research on value-added in trade flows for the final consumption of one country affecting production of another country including Noguera (2012), Bart Los Marcel P. Timmer (2018) proposing price measurement value added by country A when exporting to country B for production needs. Koopman, Wang and Wei (2014) proposed a method of analyzing a country's total exports into corresponding components of value added in a double-counted terms. Then Los et al. (2016) introduced an approach based on "hypothetical extraction" to provide a clearer definition of domestic value added in exports. Other studies relating to commercial flows include Bems et al. $(2011,2013)$.

Regarding Vietnam, the first bilateral input - output model was compiled between Vietnam and Thailand by Kim et al (2011) and recently Nguyen and Bui (2020) compiled the bilateral input - output table between Vietnam and China

\section{Data Source}

The inter-country input - output between Vietnam, China, US and EU was estimated in 2015 based on:

- Data of OECD on inter - country input - output framework, but inter - regional input - output framework of OECD does not seem a complete framework on inter-regional input - output table, due to final demand to be not decompose for each country and more over, intermediate input matrix of this inter - regional table seem only to be national input - output table of countries on diagonal of this matrix. In addition, the data in the OECD inter-regional input table - output table is also quite different from the data of countries. To compilationan inter - country input - output table between Vietnam, China, US and EU need to rely on other data such as:

- The Vietnam input - output table, 2015. This table was updated based on national input - output table in 2012 and updated data from the annual enterprise survey to estimate the ratio of intermediate cost to output; final consumption, gross capital formation, export and import and export data are based on available statistical 
reports. Then using the Ras method with random fixed point (Bui et al, 2018) was used to balance gross input and gross output.

- The input - output table in 2015 of the United States is published on the website of the US Statistical Office

- The bilateral input - output between Vietnam-China and Vietnam-US projects of the Vietnam Development Research Institute implemented in 2020.

\section{Approach}

\subsection{Framework}

Inter - country input - output framework between Vietnam, China, US and EU can be described as below:

Table 1. Inter - country input - output framework between Vietnam, China, US and EU

\begin{tabular}{|c|c|c|c|c|c|c|c|c|c|c|}
\hline & & \multicolumn{4}{|c|}{ Intermediate consumption } & \multicolumn{4}{|c|}{ Final Use } & \multirow{2}{*}{ Gross Output } \\
\hline & & $\mathrm{VN}$ & $\mathrm{CN}$ & US & EU & $\mathrm{VN}$ & $\mathrm{CN}$ & US & $\mathrm{EU}$ & \\
\hline \multirow{4}{*}{$\begin{array}{l}\text { Intermediate } \\
\text { inputs }\end{array}$} & $\mathrm{VN}$ & $\mathrm{Xvv}$ & Xvc & Xvu & Xve & Yvv & Yvc & Yvu & Yve & $\mathrm{Xv}$ \\
\hline & $\mathrm{CN}$ & $\mathrm{Xcv}$ & Xce & $\mathrm{Xcc}$ & $\mathrm{Xcu}$ & Ycv & Yce & Yce & Ycu & $\mathrm{Xc}$ \\
\hline & US & Xuv & Xuc & Xuu & Xue & Yuv & Yuc & Yuu & Yue & $\mathrm{Xu}$ \\
\hline & $\mathrm{EU}$ & $\mathrm{Xev}$ & $\mathrm{Xec}$ & $\mathrm{Xeu}$ & Xee & Yrv & Yec & Yeu & Yee & $\mathrm{Xe}$ \\
\hline ROW & & $\mathrm{M}^{\mathrm{p}} \mathrm{V}$ & $\mathrm{M}^{\mathrm{p}} \mathrm{c}$ & $\mathrm{M}^{\mathrm{p}} \mathrm{u}$ & $\mathrm{M}^{\mathrm{p}} \mathrm{e}$ & $\mathrm{M}^{\mathrm{y}} \mathrm{V}$ & $\mathrm{M}^{\mathrm{y}} \mathrm{c}$ & $\mathrm{M}^{\mathrm{y}} \mathrm{u}$ & $\mathrm{M}^{\mathrm{y}} \mathrm{e}$ & $\mathrm{M}$ \\
\hline Value added & & $\mathrm{Vv}$ & $\mathrm{Vc}$ & $\mathrm{Vu}$ & $\mathrm{Ve}$ & & & & & \\
\hline Gross input & & $\mathrm{Xv}$ & $\mathrm{Xc}$ & $\mathrm{Xu}$ & $\mathrm{Xe}$ & & & & & \\
\hline
\end{tabular}

Where:

V, C, E, U stands for Vietnam, China, US and EU respectively; ROW - Rest of the World

$\mathrm{Xij}(\mathrm{i}, \mathrm{j}=\mathrm{v}, \mathrm{c}, \mathrm{u}, \mathrm{e})$ are intermediate input matrix of country $\mathrm{j}$ used products $\mathrm{i}$

$\operatorname{Mpj}(\mathrm{j}=\mathrm{v}, \mathrm{c}, \mathrm{u}, \mathrm{e})$ are import from rest of the world of country $\mathrm{j}$ for intermediate input

Yii includes final consumption, gross capital formation and export to rest of the world, Yij presents country $\mathrm{j}$ use products of country $i$ for final consumption and gross capital formation

$\sum \mathrm{jYij}$ is final products of country $\mathrm{i}$

$\sum \mathrm{iYij}$ is final demand of country $\mathrm{i}$

$\sum \mathrm{jYij}$ is final products of country $\mathrm{i}$

Mpj is import from rest of the world for intermediate input of country $j$

$\mathrm{MY} \mathrm{j}$ is import from rest the world of country for final demand

$\mathrm{Vj}$ is value added of country $\mathrm{j}$

$\mathrm{Xj}$ is gross input/gross output of country $\mathrm{j}$

\subsection{Relationships in Inter - Country Analysis}

Put:

$$
\operatorname{Aij}=X i j / X j
$$

With:

$\mathrm{i}, \mathrm{j}=$ Vietnam, China, US and EU. Intermediate input matrix in inter - regional model (A) was decomposed by sub-matrices as below: 


$$
\mathrm{A}=\left[\begin{array}{llll}
A v v & A v c & A v u & A v e \\
A c v & A c c & A c u & A c e \\
A u v & A u c & A u u & A u e \\
A e v & A e c & A e u & A e e
\end{array}\right]
$$

And "final use" and gross output showed as follows:

$$
\mathrm{Y}=\left[\begin{array}{llll}
Y v v & Y v c & Y v u & Y v e \\
Y c v & Y c c & Y c u & Y c e \\
Y u v & Y u c & Y u u & Y u e \\
Y e v & Y e c & Y e u & Y e e
\end{array}\right]
$$$$
\mathrm{X}=\left[\begin{array}{c}
X v \\
X c \\
X u \\
X e
\end{array}\right]
$$

Put:

$$
\mathrm{B}=(\mathrm{I}-\mathrm{A})^{-1}
$$

Leontief (1936) equation is abbreviated as follow:

$$
\mathrm{X}=\mathrm{B} . \mathrm{Y}
$$

Leontief inverse matrix can be described as below:

$$
\mathrm{B}=\left[\begin{array}{llll}
B v v & B v c & B v u & B v e \\
B c v & B c c & B c u & B c e \\
B u v & B u c & B u u & B u e \\
B e v & B e c & B e u & B e e
\end{array}\right]
$$

$\sum_{\mathrm{i}} \mathrm{Bij}$ is backward linkage and $\sum_{\mathrm{j}} \mathrm{Bij}$ is forward linkage

And:

$\mathrm{Pj}=\left(\mathrm{n} \cdot \mathrm{k} \cdot \sum_{\mathrm{i}} \mathrm{Bij}\right) / \sum_{\mathrm{ij}} \mathrm{Bij}-$ Power of dispersion

$\mathrm{Si}=\left(\mathrm{n} \cdot \mathrm{k} \cdot \sum_{\mathrm{j}} \mathrm{Bij}\right) / \sum_{\mathrm{ij}} \mathrm{Bij}-$ Sensitivity for dispersion

Where: $\mathrm{n}$ is number of sectors and $\mathrm{k}$ is number countries in model; $\mathrm{Pj}$ is power of dispersion of each country and $\mathrm{Si}$ is sensitivity for dispersion of each. We can analyze as follow:

Direct impacts: $\mathrm{A}_{\mathrm{ii}}$

Indirect impacts: $\left(\mathrm{I}-\mathrm{A}_{\mathrm{ii}}\right)^{-1}-\mathrm{A}_{\mathrm{ii}}$

Multiplier impacts: $\left(I-A_{i i}\right)^{-1}$

Induced impacts: $\mathrm{Bii}-\left(\mathrm{I}-\mathrm{A}_{\mathrm{ii}}\right)^{-1}$

Spillover: $\sum_{\mathrm{i}} \mathrm{Bij}(\mathrm{i} \neq \mathrm{j})$ 
Put:

$$
\mu_{\mathrm{i}}=\mathrm{V}_{\mathrm{i}} / \mathrm{X}_{\mathrm{i}}
$$

From there, the value added of each country is divided as follows:

Value added was inducted by final products:

$$
\mu_{\mathrm{i} \cdot}\left(\mathrm{I}-\mathrm{A}_{\mathrm{ii}}\right)^{-1}
$$

The value added of country $i$ is induced by the production of other countries in model when using the product of country i as input:

$$
\mu_{\mathrm{i}} \text {. }\left(\mathrm{Bii}-\left(\mathrm{I}-\mathrm{A}_{\mathrm{ii}}\right)^{-1}\right)
$$

The final product of a country (i) not only spill over to its production value and added value but also to the production value and value added of other countries. In the case final products of Vietnam spillover to value added of China, US and EU corresponding are: $\mu_{\mathrm{c}} \mathrm{Bcv}, \mu_{\mathrm{u}} \mathrm{Buv}, \mu_{\mathrm{e}} \mathrm{Bev}$

Relation (1) can be explicitly rewritten as follows:

$$
\mathrm{X}=\left[\begin{array}{l}
X v \\
X c \\
X u \\
X e
\end{array}\right]=\left[\begin{array}{llll}
B v v & B v c & B v u & B v e \\
B c v & B c c & B c e & B c u \\
B u v & B u c & B u u & B u e \\
B e v & B e c & B e u & B e e
\end{array}\right] \times\left[\begin{array}{llll}
Y v v & Y v c & Y v u & Y v e \\
Y c v & Y c c & Y c u & Y c e \\
Y u v & Y u c & Y u u & Y u e \\
Y e v & Y e c & Y e u & Y e e
\end{array}\right]
$$

In inter-regional model $\sum_{\mathrm{j}}$ Yij presents "final products" of country I and $\sum_{\mathrm{i}}$ Yij presents "final demand" of country $\mathrm{i}$

Thus, it can be seen that the output of a country is not only produced by the final product of that country, but also induced by the end product of other countries when using those national products as inputs.

So, output is induced by final demand (Yij) as follow:

$$
\mathrm{X}=\left[\begin{array}{l}
X v \\
X e \\
X c \\
X u
\end{array}\right]=\left[\begin{array}{llll}
X v v & X v c & X v u & X v e \\
X c v & X c c & X c u & X c e \\
X u v & X u c & X u u & X u e \\
X e v & X e c & X е u & X e e
\end{array}\right]
$$

And value added ( $\mathrm{V}$ ) that induced by final demand as follow:

$$
\begin{aligned}
& V=\left(\mu_{v} . X v v+\mu_{c} . X c v+\mu_{u} . X u v+\mu_{e} . X e v, \mu_{v} . X v c+\mu_{c} . X c c+\mu_{u} . X u c+\mu_{e} . X e c, \mu_{i} . X v u+\mu_{c} . X c u+\mu_{u} . X u u\right. \\
& \left.+\mu_{\mathrm{e}} . \text { Xeu, } \mu_{\mathrm{i}} . \text { Xve }+\mu_{\mathrm{c}} . \text { Xce }+\mu_{\mathrm{u}} . \text { Xue }+\mu_{\mathrm{e}} . \text { Xee }\right)
\end{aligned}
$$

Equation (5) shown value added induced by final demand

\section{Discussion}

Table 2 shows that the United States has the lowest intermediate input over gross output in the four countries surveyed in the model; Vietnam is the country with the highest ratio of intermediate input over gross output. This means that with 100 USD output, the US has 55.8 USD of value added, the EU has 46 USD of added value, China has 32.7 USD of added value while Vietnam has only 28.8 USD value added. Table 1 also displays the import ratio in Vietnam's intermediate cost is very high, indicating that Vietnam is the primary country of outsourcing production. This ratio of China was much lower than Vietnam so the concept that China was an outsourcing production country seems to be incorrect. 
Table 2. Ratios on intermediate input, value added and import and gross output (\%)

\begin{tabular}{lllll}
\hline Unit: $\%$ & & & & \\
\hline & Vietnam & China & US & EU \\
\hline Intermediate input / Gross output & 71.2 & 67.3 & 44.2 & 54.0 \\
\hline Value added / Gross output & 28.8 & 32.7 & 55.8 & 46.0 \\
\hline Import in intermediate input & 85.0 & 7.6 & 20.0 & 18.0 \\
\hline
\end{tabular}

Source: Authors calculate

Table 2 shows that among the four countries in the model (Vietnam, China, the USand the EU), Vietnam has the lowest power of dispersion and sensitivity for dispersion indexes, while these two indicators of China are the highest. This result implies that the structure of the Chinese economy is of the highest relative importance to the countries studied in the model. It also performances that the structure of the Vietnamese economy does not have much influence on the countries surveyed in the model. The research shows that the exports of these products does not induce much to Vietnam's production and value-added but to the production and value-added of the countries where Vietnam imports raw materials as intermediate input. In fact, Vietnam's economy only produces outsourcing and assembled products

Table 3. Some general comparison of economic structure of 4 economies (times)

\begin{tabular}{lllll}
\hline Unit: times & & & & \\
\hline & Backward linkage & Power of dispersion & Forward linkage & Sensitivity for dispersion \\
\hline Vietnam & 1.485 & 0.726 & 1.122 & 0.549 \\
\hline China & 2.850 & 1.393 & 3.326 & 1.626 \\
\hline US & 1.755 & 0.858 & 1.787 & 0.874 \\
\hline EU & 2.094 & 1.024 & 1.948 & 0.952 \\
\hline
\end{tabular}

Source: Authors calculate

As can be seen in Figure 2, the induced impacts from Vietnam's final product to value added is very low about half of the spread of final product to value added of China, the US and the EU.

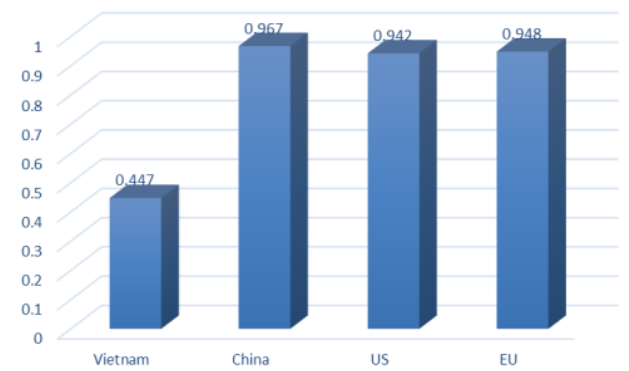

Figure 2. Value added are induced by final products (Unit: Times)

Source: Authors calculate

As shown in the previous section, the induced impacts of the final products in the country (including for domestic demand and the needs of other countries surveyed in the model) does not just induce to output and value added by that country but also spread to the value added of other countries in the model. Countries using a lot of inputfrom products of other countries in the production process will induce to output of other countries, thereby stimulating 
another countries' income generation. Table 3 shows that the induced effect of the final product on Vietnam's output is the lowest among of the four 4 countries in the model. It also presents final products of Vietnam will drive Vietnam's output and China's outputto increase by $75.4 \%$, and $22.8 \%$ respectively. On the other hand, final product of Vietnam also induces to value added of Vietnam by $72.2 \%$ and spreads to the value added of China by $24.8 \%$. This means that when Vietnamese people use their final products they also contribute to China's value added increased by $24.8 \%$. Generally, the effect of final products on China's output and the US's value-added are the best among four countries.

Table 4. Multiplier effects and spillover effects by countries to output and value added when increase a unit on final products

\begin{tabular}{lllll}
\hline Unit: $\%$ & & & & \\
\hline Vutput & Vietnam & China & US & EU \\
\hline Vietnam & & & & \\
\hline China & 75.39 & 0.06 & 0.03 & 0.03 \\
\hline US & 22.83 & 93.50 & 7.63 & 9.02 \\
\hline EU & 1.07 & 4.02 & 88.64 & 4.83 \\
\hline Value added & 0.71 & 2.42 & 3.70 & 86.11 \\
\hline Vietnam & & & & \\
\hline China & 72.16 & 0.05 & 0.01 & 0.02 \\
\hline US & 24.77 & 90.06 & 4.65 & 6.51 \\
\hline EU & 1.98 & 6.61 & 92.17 & 5.96 \\
\hline
\end{tabular}

Source: Authors calculate

Table 4 shows that the induced effect of the final product on Vietnam's output is the lowest among of the four 4 countries in the model

Table 5. Output requirement was induced by final demand

\begin{tabular}{lllll}
\hline (Unit: \%) & & & & \\
\hline & Yv & Yc & Yu & Ye \\
\hline Vietnam & 24.579 & 0.276 & 0.706 & 0.502 \\
\hline China & 67.969 & 65.257 & 9.304 & 15.574 \\
\hline US & 4.331 & 20.510 & 56.180 & 26.011 \\
\hline EU & 3.121 & 13.957 & 33.809 & 57.913 \\
\hline Output requirement (times) & $\mathbf{2 . 1 6 9}$ & $\mathbf{2 . 4 3 1}$ & $\mathbf{1 . 8 7 1}$ & $\mathbf{2 . 0 3 3}$ \\
\hline
\end{tabular}

Note: Yv is final demand of Vietnam, Yc is final demand of China, Yu is final demand of United State, Ye is final demand of EU

\section{Conclusions}

Vietnam has been engrossed in GDP growth, GDP size and trade surplus for many yearsand seems to forgetwhich ís more important. That has left significant consequences in economic structure and economic efficiency.

Certainly, comparing the economic structure between Vietnam and China, the US and the EU is unreasonable, but it can be seen that the economic structure of Vietnam is really backward and in many aspects very "primitive", less efficiency. 
To really change, it's necessary to see the problem in a transparent way and accept the truth to change. If never starts or just starts with words and slogans Vietnam will never get to the finish line.

The economic structures of China, the US and the EU show high interdependence and efficiency and are relatively flat, so it can be seen that these regions get along will make all of them well.

Vietnam needs step by step to change itself in order to have real equality of interests in bilateral and multilateral trade relations.

\section{Acknowledgment}

We would like to thank Mr. Phong N. V, Ms. Hong Dang, Ms. Hanh. N.M supported this research.

\section{References}

Bart, L., Timmer, M. P., \& Gaaitzen, J. de V. (2016). Tracing value-added and double counting in gross exports: comment. American Economic Review, 106(7), 1958-1966. https://doi.org/10.1257/aer.20140883

Geoffrey, J. D., Madden, H. M. S. M., \& Kimura, Y. (1999). Understanding and interpreting economic structure, Advances in spatial science. Springer-Verlag Berlin Heidelberg GmbH.

Ihara, T. (1999). Diagnosis and therapy of interregional feedback effects, Chapter 5. Understanding and Interpreting Economic Structure, Advances in spatial science. Springer-Verlag Berlin Heidelberg GmbH. https://doi.org/10.1007/978-3-662-03947-2_5

Isard, W. (1951). Interregional and regional input-output analysis: A model of a space-economy. Review of Economics and Statistics, 33(4), 318-328. https://doi.org/10.2307/1926459

Isard, W. (1956). Location and Space-economy; a General Theory Relating to Industrial Location, Market Areas, Land Use, Trade, and Urban Structure. Cambridge: Published jointly. Technology Press of Massachusetts Institute of Technology and Wiley.

Isard, W. (1960). Methods of regional analysis. Cambridge, MIT Press.

Kim, K. M., Secretario, F., Bui, T., \& Kaneko, H. (2011). Developing a bilateral input-output table in the case of thailand and vietnam: methodology and applications. Working Paper, 19th International Input-Output Conference.

Leontief, W. W. (1936). Quantitative input and output relations in the economic systems of the United States. The Review of Economics and Statistics, 18, 105-125. https://doi.org/10.2307/1927837

Miller, R. E. (1966). Interregional feedbacks in input-output models: some preliminary results. Papers Regional Science Association, 17, 105-125. https://doi.org/10.1007/BF01982512

Miller, R. E. (1969). Interregional feedbacks in input-output models: some experimental results. Western Economic Journal, 7, 57-70. https://doi.org/10.1111/j.1465-7295.1969.tb01462.x

Miyazawa, K. (1960). Foreign trade multiplier, input-output analysis and the consumption function. Quarterly Journal of Economics, 14, 53-64. https://doi.org/10.2307/1884133

Miyazawa, K. (1966). Internal and external matrix multipliers in the input-output model. Hitotsubashi Journal of Economics, 7, 38-55.

Miyazawa, K. (1968). Input-output analysis and interrelational multiplier as a matrix. Hitotsubashi Journal of Economics, 8, 39-58.

Miyazawa, K. (1971). An analysis of the interdependence between service and goods producing sectors. Hitotsubashi Journal of Economics, 12, 10-21.

Miyazawa, K. (1976). Input-output analysis and the structure of income distribution. Heidelberg, Springer-Verlag. https://doi.org/10.1007/978-3-642-48146-8

Noguera, G. (2012). Trade costs and gravity for gross and value added trade. University of California at Berkeley and Columbia University, Mimeo.

Quang, T. N., Trinh, B., Thang, L. N., \& Manh, D. T. (2020). Analysis of Bilateral Input-Output Trading between Vietnam and China. Journal of Asian Finance, Economics and Business, 7(6), 157-172. https://doi.org/10.13106/jafeb.2020.vol7.no6.157

Richardson, H. W. (1979). Regional economic. Urbana, University of Illinois Press. 
Robert, K., Wang, Z., \& Wei, S.-J. (2014). Tracing value-added and double counting in gross exports. American Economic Review, 104(2), 459-494. https://doi.org/10.1257/aer.104.2.459

Rudolfs, B., Johnson, R. C., \& Yi, K.-M. (2011). Vertical linkages and the collapse of global trade. American Economic Review (Papers and Proceedings), 101(3), 308-312. https://doi.org/10.1257/aer.101.3.308

Sonis, M., \& Geoffrey, J. D. H. (1993). Hierarchies of Regional Sub-Structures and their Multipliers within Input-Output Systems: Miyazawa Revisited. Hitotsubashi Journal of Economics, 34, 33-44.

Sonis, M., \& Geoffrey, J. D. H. (1995). Matrix sensitivity, error analysis andinternal/external multiregional multipliers. Hitotsubashi Journal of Economics, 36, 61-70.

Timmer, B. L. M. P. (2018). Measuring bilateral exports of value added: a unified framework. Working Paper 24896. Retrieved from http://www.nber.org/papers/w24896

Trinh, B., Phong, N. V., \& Quoc, B. (2018). The RAS method with random fixed points. Journal of Economics and Business, 1(4), 640-646. https://doi.org/10.31014/aior.1992.01.04.57

\section{Notes}

Note 1. https://www.oecd.org/sti/ind/inter-country-input-output-tables.htm

Note 2. https://www.bea.gov/industry/input-output-accounts-data

\section{Copyrights}

Copyright for this article is retained by the author(s), with first publication rights granted to the journal.

This is an open-access article distributed under the terms and conditions of the Creative Commons Attribution license (http://creativecommons.org/licenses/by/4.0/). 